\title{
Drinking Water Risk Management Plan: A Case Study in the Ore Processing Industry
}

\author{
Arif Susanto $1,2,3, * \mathbb{C}$, Purwanto Purwanto ${ }^{1,4}$, Edi K. Putro ${ }^{3}$ and Fanny Yuliasari ${ }^{3}$ \\ 1 Doctorate Program in Environmental Science, School of Postgraduate Studies, Universitas Diponegoro, \\ Semarang 50241, Indonesia \\ 2 Study Program in Environmental Engineering, Faculty of Civil and Environmental Engineering, \\ Universitas Kebangsaan Bandung, Bandung 40263, Indonesia \\ 3 Safety Health and Environmental Department, Division of Concentrating, PT Freeport Indonesia, \\ Tembagapura 50725, Indonesia \\ 4 Department of Chemical Engineering, Faculty of Engineering, Universitas Diponegoro, Semarang 50275, \\ Indonesia \\ * Correspondence: arifssnt@yahoo.com
}

Received: 4 June 2019; Accepted: 19 August 2019; Published: 23 August 2019

\begin{abstract}
All of the water supply system development needs to be safe and meet health requirements. Due to the expansion of the ore processing industry, water supply providers are required to identify the risks that may arise from dangerous and hazardous events. The purpose of this study was to build a structured approach to drinking water risk management plans (RMPs). We used risk assessments with reference to the environmental management system, risk management, and the food safety management system. The results of the risk assessment show two critical control points (CCPs) of high risk: Dam (catchment) and pipe reticulation. Some CCPs were categorized as posing very high risks of hazardous events due to pathogen contamination, including the clean water tank, the disinfectant injector, and pipe reticulation. The RMPs recorded and identified various preventive measures that could be taken to reduce and eliminate the risks. Daily operational requirements can be implemented to prepare for these hazards and risks that have the potential to negatively affect the quality of the drinking water supplied to the workers. Risk assessments were conducted in two stages: Preventive measures and operational monitoring. The involvement of all departments and authority agencies was crucial to ensure the success in the development and review of the operational aspects of these RMPs.
\end{abstract}

Keywords: drinking water; hazardous event; risk assessment; risk management plans (RMPs)

\section{Introduction}

Indonesia has a national waste management policy under Article 19 of the Law Constitution Number 18 of 2008 [1], which was followed by the Circular Letter of the Ministry of Environment and Forestry of the Republic of Indonesia Number SE.3/UM/RT/SET.1/2/20018, which prohibited the use of plastic packaging of drinking water in the mining work environment [2]. To implement these regulations, a suitable drinking water supply system [3] must be developed that meets the basic health requirements and can be consumed directly [4]. This development aims to expand and improve the physical (technical) and non-physical systems (institutional, management, finance, community roles, and law) together to enable the provision of safe drinking water to the public [3].

The provision of safe drinking water needs to meet physical, microbiological, chemical, and radioactive requirements $[4,5]$, which provide the minimum required and additional parameter details. The minimum requirements involve drinking water quality obligations that must be followed 
and adhered to by all operators. To maintain a high quality of drinking water for community consumption, supervision checks are performed. Internal supervision is conducted by providers to guarantee high water quality; this includes sanitation inspection, water sampling, water quality testing, and analysis of laboratory test results, recommendations, and follow-up [3-5].

An effective method of consistently ensuring the safety of drinking water is through the use of comprehensive risk assessments and management as they encompass all the important steps regarding water supply, from water sources to the consumers [5,6]. The World Health Organization (WHO) provides a risk-based framework consisting of several components to manage the safety of drinking water [5], which involves the use of health-based targets (HBTs) to determine the level of contaminants within drinking water [4,7], use of water safety plans that include identification of hazards and necessary control measures [6], process monitoring, and system management implementation [8].

Risk assessments and management are a significant part of water safety plans (WSPs) and aim to minimize the contamination of water sources. They also include reduction or removal of contaminated substances during storage, distribution, and treatment of drinking water [5]. Hazard identification and risk assessment (HIRA) is the starting point for these risk management plans (RMPs) [6,7]. The main component is a rating system used to determine the supply chain that can produce quality water that meets HBTs and identify measures to control the identified risks and ensure that HBTs are met. RMPs can also be used for planning supervision by describing crucial actions that need to be taken during normal operation or emergency (abnormal) conditions $[5,6,9]$.

The purpose of this study was to build a structured approach to drinking water risk management plans (RMPs). We used risk assessments with reference to the environmental management system, risk management, and the food safety management system. The RMPs recorded and identified various preventive measures that could be taken to reduce and eliminate the risks.

\section{Materials and Methods}

The process used for the administration of clean drinking water adopts the same philosophy as the WHO guidelines [5] for a system that is used in the risk assessment of environmental management systems (EMSs) ISO14001:2015 [10], risk management (RM) ISO31000:2018 [11], and food safety management systems (FSMSs) ISO22000:2018 [12]. The purpose of this study was to build a structured drinking-water risk management plan (RMP) for the development of effective drinking water supply systems, especially in areas hosting the ore processing industry. Ore mining occurs in the Mimika Regency region, Papua Province, Indonesia [13], with a working population of more than 2000 people as shown in Figure 1, which is categorized as an average number of drinking water consumers [6].

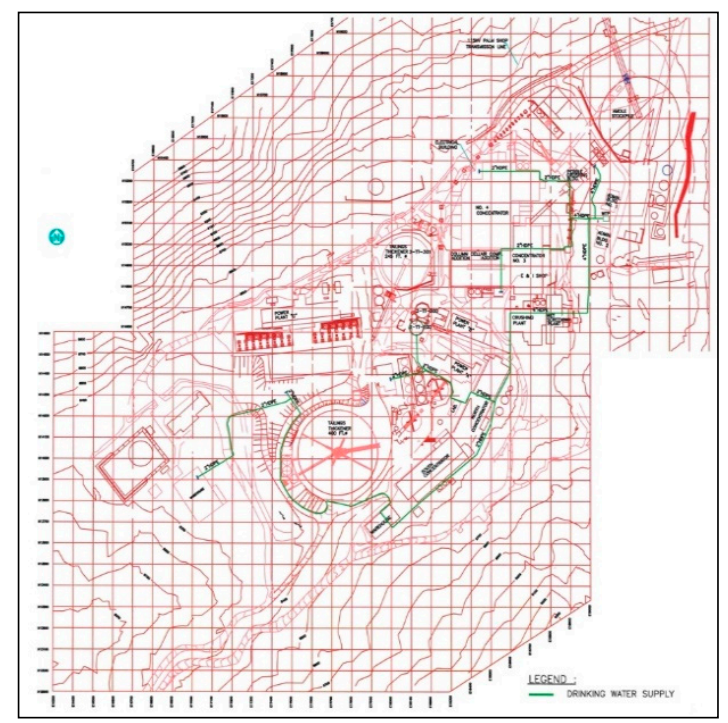

Figure 1. Case study area of the main water distribution line. 
We used a semi-quantitative matrix approach, a five-cell risk assessment format that applies technical information from the regulations $[4,5,14,15]$, different color background of categories shown of severity of consequences, as illustrated in Table 1. With this semi-quantitative assessment, control measures can be organized starting with the most severity significant danger. The application of this matrix depends on the significance of the health risks posed by the hazardous event. The risks can be categorized by identifying their likelihood of occurrence and by evaluating the severity of the consequences, as illustrated in Table 2. The cut-off point is determined by any danger that requires immediate attention. Risks must be assessed with the aim of distinguishing between the greater and lesser important hazardous events, so that a risk management priority order can be established and documented. This is imperative because, although many contaminants can deteriorate the quality of drinking water, not every hazard requires the same level of attention [5].

Table 1. Five-cell risk assessment matrix for drinking water risk management plans (RMPs).

\begin{tabular}{cccccccc}
\hline \multirow{2}{*}{ Likelihood } & \multicolumn{9}{c}{ Severity of Consequences } & \multirow{2}{*}{$\begin{array}{c}\text { Cut-Off Point and Meaning of the } \\
\text { Color }\end{array}$} \\
\cline { 2 - 6 } & Insignificant & Minor & Moderate & Major & Catastrophic & 1-5: low risks (green) \\
\hline Almost certain & 5 & 10 & 15 & 20 & 25 & 6-9: medium risks (yellow) \\
Likely & 4 & 8 & 12 & 16 & 20 & $10-15:$ high risks (orange) \\
Moderate likely & 3 & 6 & 9 & 12 & 15 & 16: very high risks (red) \\
Unlikely & 2 & 4 & 6 & 8 & 10 & \\
Rare & 1 & 2 & 3 & 4 & 5 & \\
\hline
\end{tabular}

Table 2. Likelihood and severity categories in risk assessment for drinking water RMPs.

\begin{tabular}{lcc}
\hline \multicolumn{2}{c}{ Likelihood Categories } \\
\hline$(1)$ & Rare & Once every 5 years \\
$(2)$ & Unlikely & Once per year \\
$(3)$ & Moderate likely & Once per month \\
$(4)$ & Likely & Once per week \\
$(5)$ & Almost certain & Once per day \\
\hline \multicolumn{2}{c}{ Severity Categories } \\
\hline$(1)$ & Insignificant & No impact or not detectable \\
$(2)$ & Minor & Impact to compliance \\
$(3)$ & Moderate & Impact to aesthetic \\
$(4)$ & Major & Impact to regulatory \\
$(5)$ & Catastrophic & Impact to public or human health \\
\hline
\end{tabular}

\section{Results}

The risk assessment in this study involved the drinking water supply system that is described in Figure 2. The assessment included the distribution of water supplies that previously existed plus the plans to add a new water treatment system unit. The system had been adjusted to serve the required number of consumers according to the estimated increase in workers, as well as potential sources of hazards. The amount of pipes leakage each month was recorded along with the number of potential consumers who might be affected. The data were collected and analyzed for the preparation of hazard risk maps, as shown in Table 3.

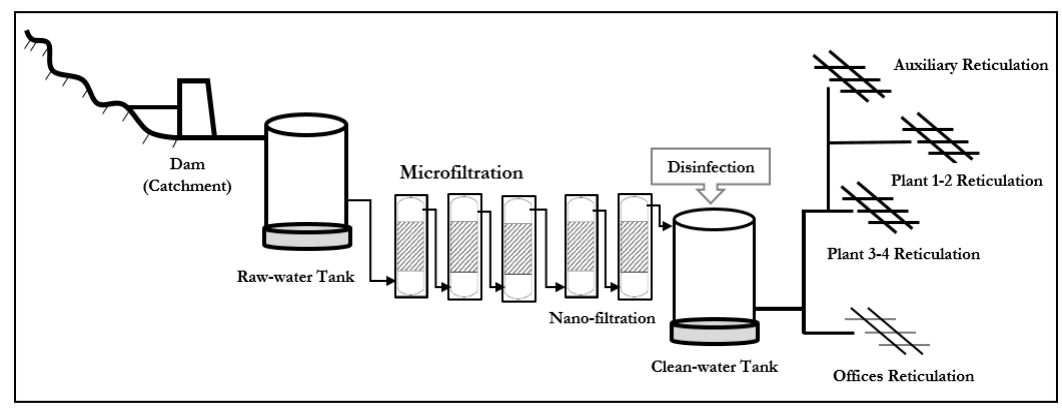

Figure 2. Schematic layout of the drinking water supply system. 
Table 3. Results of HIRA in drinking water RMPs.

\begin{tabular}{|c|c|c|c|c|c|}
\hline \multirow{2}{*}{ Hazard Type } & \multicolumn{2}{|c|}{ Hazardous Event } & \multirow[b]{2}{*}{ Risk } & \multirow[b]{2}{*}{ Score } & \multirow{2}{*}{ Color \& Category } \\
\hline & What & Where & & & \\
\hline Aesthetic & $\begin{array}{l}\text { Sediment, grit } \\
\text { contamination }\end{array}$ & Dam & $\begin{array}{l}\text { Increase in color, } \\
\text { turbidity, and taste }\end{array}$ & 10 & $\begin{array}{l}\text { Orange: } \\
\text { High risk }\end{array}$ \\
\hline Health & Fecal contamination & Dam & $\begin{array}{l}\text { Illness due to ingestion } \\
\text { of pathogens }\end{array}$ & 10 & $\begin{array}{l}\text { Orange: } \\
\text { High risk }\end{array}$ \\
\hline Aesthetic & $\begin{array}{l}\text { Materials compound } \\
\text { leaching }\end{array}$ & Raw water tank & Odor and taste issues & 3 & $\begin{array}{l}\text { Green: } \\
\text { Low risk }\end{array}$ \\
\hline Aesthetic & $\begin{array}{l}\text { Coatings compound } \\
\text { leaching }\end{array}$ & Raw water tank & Odor and taste issues & 3 & $\begin{array}{l}\text { Green: } \\
\text { Low risk }\end{array}$ \\
\hline Health & $\begin{array}{l}\text { Materials compound } \\
\text { leaching }\end{array}$ & Raw water tank & $\begin{array}{l}\text { Illness due to ingestion } \\
\text { of chemicals }\end{array}$ & 5 & $\begin{array}{l}\text { Green: } \\
\text { Low risk }\end{array}$ \\
\hline Health & $\begin{array}{l}\text { Coatings compound } \\
\text { leaching }\end{array}$ & Raw water tank & $\begin{array}{l}\text { Illness due to ingestion } \\
\text { of chemicals }\end{array}$ & 5 & $\begin{array}{l}\text { Green: } \\
\text { Low risk }\end{array}$ \\
\hline Aesthetic & $\begin{array}{l}\text { Anaerobic growth in } \\
\text { accumulated sediment }\end{array}$ & Raw water tank & Odor issues & 3 & $\begin{array}{l}\text { Green: } \\
\text { Low risk }\end{array}$ \\
\hline Health & Pathogen contamination & $\begin{array}{c}\text { Clean water } \\
\text { tank }\end{array}$ & $\begin{array}{l}\text { Illness due to ingestion } \\
\text { of pathogens }\end{array}$ & 25 & $\begin{array}{l}\text { Red: } \\
\text { Very high risk }\end{array}$ \\
\hline Health & $\begin{array}{l}\text { Low disinfectant } \\
\text { injection }\end{array}$ & $\begin{array}{l}\text { Disinfection } \\
\text { injector }\end{array}$ & $\begin{array}{l}\text { Low free residual } \\
\text { chlorine (FRC) }\end{array}$ & 25 & $\begin{array}{l}\text { Red: } \\
\text { Very high risk }\end{array}$ \\
\hline Health & Pathogen contamination & $\begin{array}{l}\text { Pipe } \\
\text { reticulation }\end{array}$ & $\begin{array}{l}\text { Illness due to ingestion } \\
\text { of pathogens }\end{array}$ & 25 & $\begin{array}{l}\text { Red: } \\
\text { Very high risk }\end{array}$ \\
\hline Aesthetic & $\begin{array}{l}\text { Sediment, grit } \\
\text { contamination }\end{array}$ & $\begin{array}{l}\text { Pipe } \\
\text { reticulation }\end{array}$ & $\begin{array}{l}\text { Increase in color, } \\
\text { turbidity, and taste }\end{array}$ & 15 & $\begin{array}{l}\text { Orange: } \\
\text { High risk }\end{array}$ \\
\hline
\end{tabular}

Figure 2 explains how the operating unit, in the form of a screen cleaning on the dam, functions to hold coarse solids (leaves, wood, animal carcasses, etc.) floating or drifting in the water so they are not carried into the next processing unit. Screen cleaning is periodically conducted manually by removing objects that are trapped in the dam and should not exceed the half-clogged condition to ensure the head loss does not exceed the specified limit. This head loss is calculated on a clean screen and on half-clogged screen conditions [16,17]. Microfiltration is used in this water treatment through a low-pressure cross-flow membrane to separate colloidal and suspended particles (measuring from 0.05 to 1 microns) and to remove turbidity, iron and manganese precipitates, coagulated organics, and pathogens such as Giardia and Cryptospiridium cysts [5,18].

\section{Discussion}

In this study, drinking water RMP is defined as efforts to safeguard drinking water supplies, both in terms of quality and quantity. The quality aspect involves preventing pollution, whereas the quantity aspect includes catchment to the water tap, to every employee's shop, and to offices. This is conducted by various parties in an integrated manner using analysis and risk management approaches. The main objective of the implementation of these policies is to ensure the safety of drinking water supply and involves:

(1) Creating drinking water management and services that guarantee aspects of quality, quantity, continuity, and affordability;

(2) Developing a balanced interest between consumers and suppliers of drinking water services; and

(3) Improving the efficiency and coverage of drinking water services in the ore processing industry work area.

The WHO provides an approach for the management of contaminated substances in drinking water sources, namely HBTs, which consist of four targets to successfully accomplish the drinking water safety and health requirements: Health outcome targets, specified technology targets, performance targets, and water quality targets. The source of drinking water in this industrial area is the surface runoff that is captured in a basin and maintained in the reservoir tank. It then flows through a pipeline to the treatment plant, as illustrated in Figure 2. The water sources in this study area are abundant; in the three years of rainfall measurements from 2016 to 2018, the average rainfall was $447.54 \mathrm{~mm}$ 
with a minimum rainfall of $138.80 \mathrm{~mm}$ and a maximum of $745.80 \mathrm{~mm}$, as illustrated in Figure 3. This condition is not expected to noticeably vary each year in the future based on the cycle projections of 100 years.

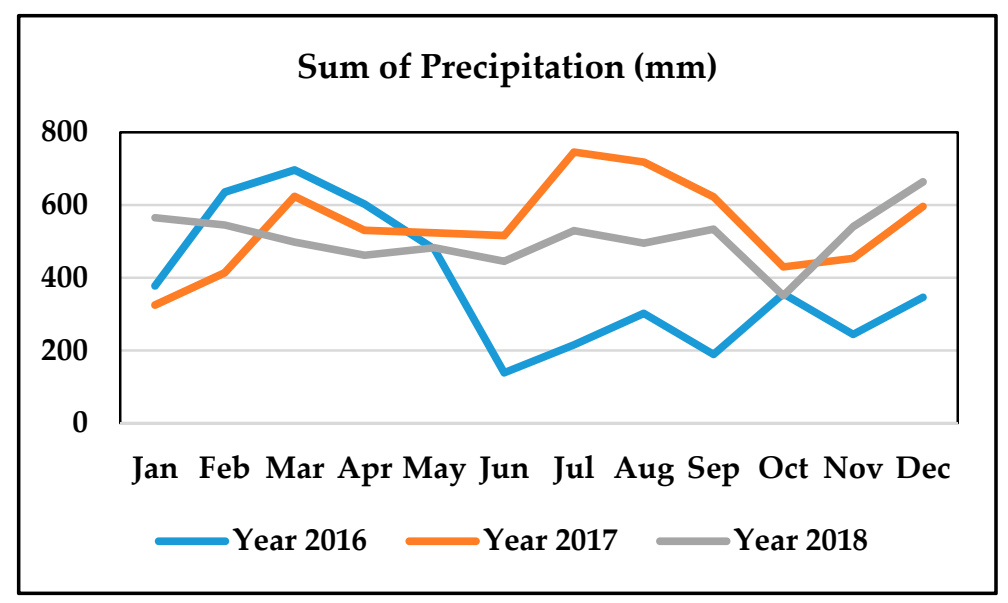

Figure 3. Sum of precipitation in the ore processing industry area in Indonesia.

When assessing water quality of raw water sources, the Storage and Retrieval (STORET) method is used [14] to understand the water quality standards that have been met or exceeded. In principle, this method compares the water quality data with the standard, which is adjusted based on its purpose to determine the water quality status. The quality classification consists of four classes: A, which is very good with a score of zero (meets the quality standards); B, which is good with a score of -1 to -10 (light pollution); $\mathrm{C}$ is moderate with a score of -11 to -30 (moderate pollution); and $\mathrm{D}$ is bad, with a score of less than -30 (severe pollution).

The scope of production that is described in Figure 2 involves processing raw water from the surface into drinking water. A series of both physical and chemical processes are completed. A drinking water safety plan includes a number of aspects, including: (1) Intake or storage, (2) treatment units, and (3) distribution units in the form of piping systems that deliver processed water to employees. The system depicted covers all components of drinking water supply including: Raw water sources, intake system, transmission structure, installation of water treatment, transmission and reservoir systems, and network of distribution pipelines to the connections in the customers' homes. The supply chain created must be able to describe the whole process and its level of detail must be appropriate to allow for modification to include hazard and risk events.

The quality water sources are controlled to prevent a decrease in their condition and use, which disrupt and endanger health [15]. This includes field observations, water sampling, laboratory tests [16], analysis of test results, formulation of suggestions, problem-solving methods, follow-up activities in the form of repair work monitoring, and prevention efforts including extension activities [15]. The characteristics of water sources obtained from the test are provided in Table 4. The water meets the quality standards of class A.

The purposes of HIRA include identifying potential hazardous events that might arise in the supply chain and estimating the risks generated, assigning each risk-factor a score. An inventory of hazardous events is completed by referring to the recorded data, for example, from damage to the pump, and recorded activities, involving repairing pipeline leaks and others. One of the disadvantages of using the matrix method in assessing the magnitude of risk is the possibility of disagreements among drinking water RMPs. To overcome this problem, tracing back past hazard events data obtained from related documents is important. For example, maintenance, purchase of tools and materials, and severity assessment are also based on real data.

As described in Table 3, the risks can be identified at various stages consisting of its likelihood and severity $[16,19]$. Upon conducting risk analysis, the weighting of the factors was adjusted as shown 
in Table 1. This method is similar to the weighting process that is applied for the risk assessment of water systems in Australia [20] and Uganda [21], but the difference is that a risk score of one indicates very low risk based on severity, a score of two indicates a low risk, a score of three indicates a moderate risk, a score of four indicates a high risk, and a score of more than five indicates a very high risk [5]. Therefore, the selection of criteria and weighting that is used in this method is different from that applied by Australia and Uganda because they do not have the same industry standards [16]. The assessment of the possible impact of the severity on water supply distributed through the pipeline is based on the severity scale [5] as shown in Table 2.

Table 4. Laboratory tests of raw water source quality.

\begin{tabular}{|c|c|c|c|c|c|c|}
\hline \multirow{2}{*}{ Parameter } & \multirow{2}{*}{ Unit } & \multirow{2}{*}{ Methods [22] } & \multicolumn{2}{|c|}{ Raw Water Quality } & \multicolumn{2}{|c|}{ Drinking Water } \\
\hline & & & Results & Standard [4] & Results & Standard [5] \\
\hline $\mathrm{pH}$ & - & SNI06-1140-1989 & $7.88-8.29$ & $6.5-9.0$ & $7.30-7.45$ & $6.5-8.5$ \\
\hline Total Dissolved Solids & $\mathrm{mg} / \mathrm{L}$ & SNI06-1136-1989 & $298-322$ & 1500 & $383-394$ & 500 \\
\hline Turbidity & NTU & SNI06-2413-1991 & $0.35-0.86$ & 25 & $0.32-0.58$ & 5 \\
\hline Color & TCU & SNI06-2413-1991 & $<3$ & 50 & $<3$ & 15 \\
\hline Mercury & $\mathrm{mg} / \mathrm{L}$ & SNI06-2912-1992 & $<0.0003$ & 0.001 & $<0.0003$ & 0.001 \\
\hline Arsenic & $\mathrm{mg} / \mathrm{L}$ & SNI06-2463-1991 & $<0.005$ & 0.05 & $<0.005$ & 0.01 \\
\hline Iron & $\mathrm{mg} / \mathrm{L}$ & SNI06-4138-1996 & $0.0013-0.0205$ & 1.0 & $0.013-0.0174$ & 0.3 \\
\hline Fluoride & $\mathrm{mg} / \mathrm{L}$ & SNI06-2482-1991 & 0.06-0.08 & 1.5 & $<0.07$ & 1.5 \\
\hline Cadmium & $\mathrm{mg} / \mathrm{L}$ & SNI06-2466-1991 & $<0.001$ & 0.005 & $<0.001$ & 0.003 \\
\hline Hardness $\left(\mathrm{CaCO}_{3}\right)$ & $\mathrm{mg} / \mathrm{L}$ & SNI06-4161-1996 & $315-322$ & 500 & $373-391$ & 500 \\
\hline Chloride & $\mathrm{mg} / \mathrm{L}$ & SNI06-2431-1991 & $2.28-2.49$ & 600 & $2.68-2.72$ & 250 \\
\hline Manganese & $\mathrm{mg} / \mathrm{L}$ & SNI06-2497-1991 & 0.001 & 0.5 & $0.001-0.002$ & 0.4 \\
\hline Nitrate (as N) & $\mathrm{mg} / \mathrm{L}$ & SNI06-2480-1991 & $<0.01$ & 10 & $<0.01$ & 50 \\
\hline Nitrite (as N) & $\mathrm{mg} / \mathrm{L}$ & SNI06-2484-1991 & $<0.01$ & 0.1 & $<0.01$ & 3 \\
\hline Selenium & $\mathrm{mg} / \mathrm{L}$ & SNI06-2475-1991 & $<0.005$ & 0.01 & $<0.005$ & 0.01 \\
\hline Zinc & $\mathrm{mg} / \mathrm{L}$ & SNI06-2500-1991 & $0.014-0.122$ & 15 & $0.29-0.308$ & 3 \\
\hline Sulfate & $\mathrm{mg} / \mathrm{L}$ & SNI06-2426-1991 & $128-142$ & 400 & $173-174$ & 250 \\
\hline Lead & $\mathrm{mg} / \mathrm{L}$ & SNI06-2518-1991 & $<0.005$ & 0.05 & $<0.005$ & 0.01 \\
\hline Total coliform & MPN & SNI06-4158-1996 & 50 & 50 & 0 & 0 \\
\hline
\end{tabular}

The risks can vary based on the type of hazard, such as pathogens or pollution by hazardous substances, because low levels of exposure to chemicals can cause serious illnesses in the long-term [23,24]. The impact of these short- and long-term exposures should be considered when determining risk severity. Leaks in the main transmission pipes rather than in the additional pipes will affect more people [16]. The weighting consideration in this risk assessment was completed considering the event data from the prior three years. Data for each hazardous event were collected based on each incident that occurred throughout the year. The risk score obtained is based on the results of its likelihood and severity $[13,16]$. Table 5 provides further details: The results of the high-risk assessment category show two critical control points (CCPs): In the dam and pipe reticulation. A very high category hazardous event was caused by pathogen contamination in some CCPs: In the clean water tank, disinfectant injector, and pipe reticulation.

Preventive measures aim to provide alternative methods for coping with hazards and their risks including how to validate alternative control measures. These are steps taken to eliminate or reduce hazards and risk events in the supply chain system of drinking water to guarantee the availability of safe drinking water. The list of control measures needs to be drafted to serve as a reference for companies handling risks. A list containing multiple barriers or choices can act as a useful backup if one control measure fails to successfully address hazard and risk events. Monitoring water quality is not a preventive measure [25-28] because it needs to be related to a corresponding action. For example, if a laboratory examination reports microbiology parameters, then the investigation of contamination must be registered to the preventive measure. Corresponding action is completed by establishing an RMP team where each personnel is assigned a task to complete to ensure that the drinking water consumed by employees in the industrial area fulfills the requirements [5,15]. 
Table 5. Preventive measure and corrective action based on hazard identification and risk assessment (HIRA) results.

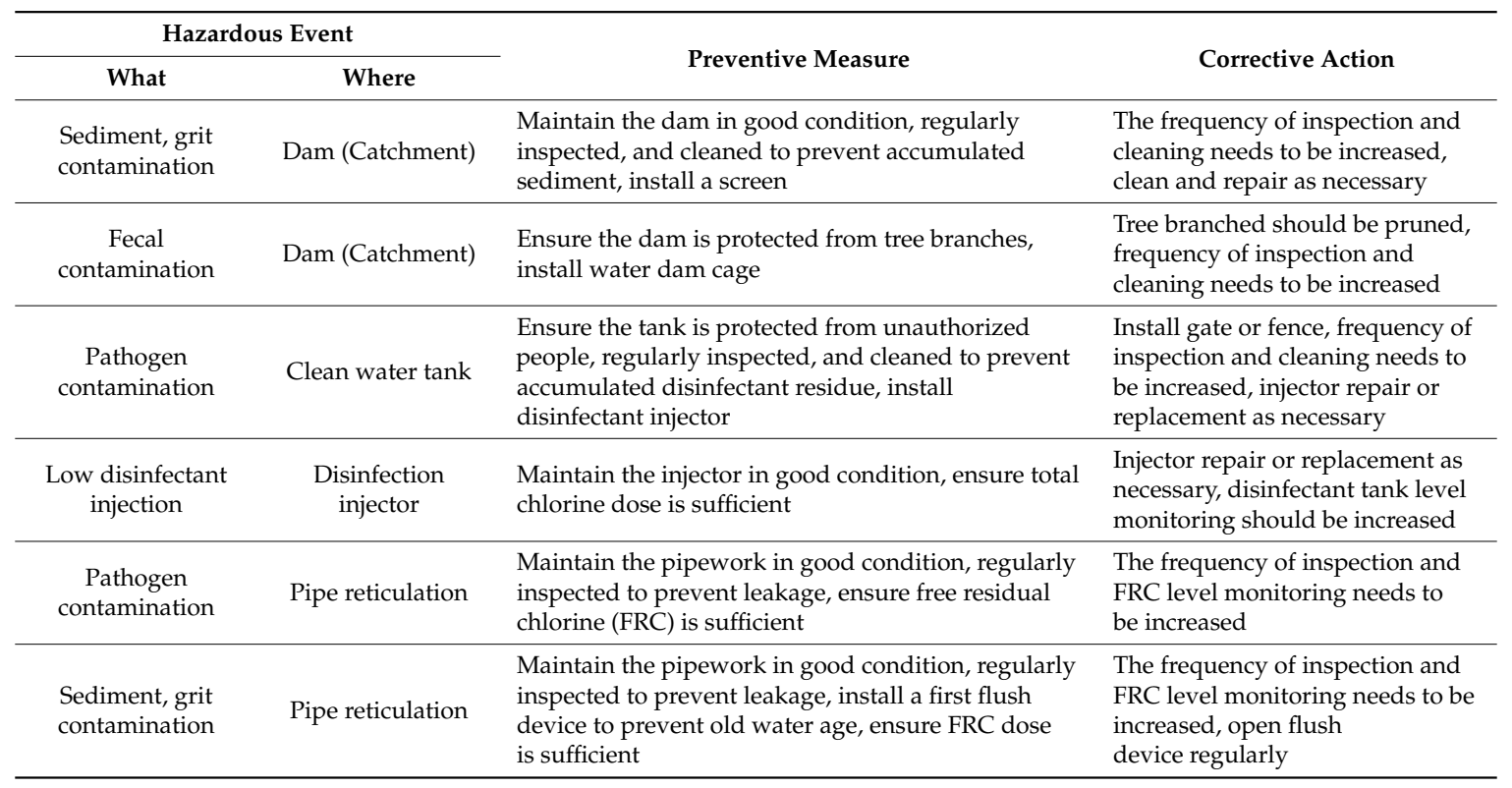

The preventive measures used might be: (1) Short term, such as those related to daily tasks and work instructions, or (2) long-term issues relating to improving the quality and continuity of water sources. Table 5 presents control measures for several hazardous events. To ensure the effectiveness of control measures, validation is necessary. This is different from monitoring, which emphasizes activities to determine whether a control action was successful. For control measures used (existing), a validation process is not needed. Observation data on the performance of the existing control measures are used as a basis if the existing control measures are replaced with others. Preventive measures are validated from technical theory, specifications of equipment from the factory, information from the operation manual, conducting a pilot (pilot study) or plant test, and recording operational monitoring data. The number and type of preventive measures for each system should be different. This depends on the frequency of occurrences of hazards and their risks and types. Monitoring is also needed to determine whether differences exist between the target and the results obtained for the completed corrective actions.

Quality supervision in industrial areas is intended to assess the health of workers. A security review is conducted and drinking water supplies are investigated. This contributes to the health protection of workers by fulfilling predetermined HBTs. In addition, quality supervision can provide an indicator of drinking water distribution services, including quality, quantity, accessibility, and continuity of supply $[5,29,30]$. All employees receive drinking water in several different ways: From pipes with no pumping (due to possible elevation and contour of the land) and delivery by tanker trucks for several shops where it is not possible to supply through pipes. We used a library system that distributes water that meets the requirements according to the regulations of the Ministry of Health of the Republic of Indonesia.

The pipelines distributing water to consumers must be in good condition. Hazards occurring due to old, porous, and leaky pipes have been eliminated since all distribution pipelines are new. However, there is a possibility that these dangers will occur; therefore, the risk severity score is very high. Contaminated groundwater leaking into pipes is a major concern and this risk can be assessed by monitoring and analyzing the condition of the pipe, e.g., age of the pipe, pipe materials, and corrosiveness of the soil. Very high risk indicates that the water contamination occurs by pathogen contamination and resulting illness due to ingestion of pathogens, as shown in Table 3. The population of employees for various zones are calculated by multiplying the employees' density. High-density 
polyethylene (HDPE) is selected by the government of Indonesia, since it has good flexibility and corrosion resistance for the restoration of the water conduits.

The drinking water quality was surveyed and the data are shown in Table 4, including results after the installation of a new water treatment system. Follow-up procedures are needed to ensure that corrective actions are taken properly. Supervision is conducted by three authority institutions: The Department of Public Health, Department of Water-Sewerage-Wastes, and the Department of Environmental Protection. Water quality monitoring has to provide information for all employees regarding the quality of drinking water supply in each work area, especially for daily monitoring, which consists of several parameters: Free residual chlorine (FRC), $\mathrm{pH}$, and turbidity. The microbiology parameter is monitored weekly and certain chemicals that have a direct impact on health are monitored every month. This exceeds the requirements set by the government, which state that microbiological and chemical checks should be conducted quarterly [4].

This supervision is also used to ensure that all possible nonconformities are investigated and resolved quickly and precisely as part of a collaboration between public health agencies, drinking water suppliers, and consumers to increase the drinking water quality. Such supervision must include the RMP approval process and involves a review of the system assessment, identification of appropriate control measures, operational monitoring, and risk management [5]. RMPs include normal operating conditions and irregular incidents, as well as an emergency plan in the case of the emergency or unplanned event.

\section{Conclusions}

Drinking water risk management plans (RMPs) document the water assessment and risk management processes. They also provide the basis for maintaining and improving the safety of the drinking water supply. The success of an RMP is comparable to the safety and health requirement level that is implemented as a part of the daily provision of drinking water in the study area. These RMPs must be made available to all relevant departments and authorities. Operational experience shows that there are opportunities to be stricter than the regulations provided by the Indonesian government and standards that are referenced for achieving HBTs. The involvement of all departments agencies is crucial to the successful development and review of the operational aspects of these RMPs. Information on surveillance results is an important part of the drinking water quality management plan for workers in the study area, in addition to the implementation of risk management, which is a preventive measure and a corrective action.

Author Contributions: Conceptualization, A.S. and E.K.P.; methodology, A.S. and P.P.; software, A.S.; validation, A.S., P.P. and F.Y.; formal analysis, A.S.; investigation, F.Y.; resources, E.K.P.; data curation, A.S.; writing—original draft preparation, A.S.; writing - review and editing, A.S.; visualization, F.Y.; supervision, P.P. and E.K.P.; project administration, F.Y.; funding acquisition, E.K.P.

Funding: This project received no additional funding.

Acknowledgments: The authors of this case study would like to acknowledge the Environmental \& Health Section, Department of Health Safety and Environmental, Division of Concentrating PT Freeport Indonesia for their assistance with the completion of this project.

Conflicts of Interest: The authors declare that there is no conflict of interest.

\section{References}

1. Law of the Republic of Indonesia. No. 18 Year 2008 about Waste Management. Gazette No. 4852. Available online: https://www.bphn.go.id/data/documents/08uu018.pdf (accessed on 22 March 2019).

2. Ministry of Energy and Mineral Resources. Circular Letter No. 704/37/04/DBT/2019 about Prohibition of the Use of Plastic Packaging of Drinking Water in the Mining Work Environment; Directorate of Energy and Mineral Resources, Ministry of Energy and Mineral Resources of the Republic of Indonesia: Jakarta, Indonesia, 2019.

3. Regulation of Ministry of General Works of the Republic of Indonesia. No. 18/PRT/M/2007 about Implementation of Development of Drinking Water Supply Systems. Available online: http://ciptakarya.pu. 
go.id/plp/upload/peraturan/Permen_PU_No_18_Tahun_2007_-_Penyelengaaraan_SPAM.pdf (accessed on 23 March 2019).

4. Regulation of Ministry of Heath of the Republic of Indonesia. No. 492/MENKES/PER/IV/2010 about Drinking Water Quality Requirements. Available online: http://www.ampl.or.id/digilib/read/24-peraturan-menterikesehatan-republik-indonesia-no-492-menkes-per-iv-2010/50471 (accessed on 23 March 2019).

5. WHO. Guidelines for Drinking-Water Quality, 4th Edition, Incorporating the 1st Addendum. Available online: https://www.who.int/water_sanitation_health/publications/drinking-water-quality-guidelines-4including-1st-addendum/en/ (accessed on 22 March 2019).

6. South Australia Health. Risk Management Plans for Drinking Water Providers. Available online: https://www.sahealth.sa.gov.au/wps/wcm/connect/public+content/sa+health+internet/protecting+public+ health/water+quality/providing+safe+drinking+water/risk+management+plans+for+drinking+water+ providers (accessed on 23 March 2019).

7. USEPA. Ground Water and Drinking Water. Available online: https://www.epa.gov/ground-water-anddrinking-water/national-primary-drinking-water-regulation-table (accessed on 22 March 2019).

8. Monis, P.; Lau, M.; Harris, M.; Cook, D.; Drikas, M. Risk-based management of drinking-water safety in Australia: Implementation of health based targets to determine water treatment requirements and identification of pathogen surrogates for validation of conventional filtration. Food Waterb. Parasitol. 2017, 8 , 64-74. [CrossRef]

9. Department of Natural Resources, Mineral and Energy. Drinking Water Quality Management Guideline. Available online: https://www.dews.qld.gov.au/_data/assets/pdf_file/0010/45586/dwqmp-guidelines.pdf (accessed on 22 March 2019).

10. International Standard Organization, Geneva. ISO 14001:2015 Environmental Management System—Requirements with Guidance for Use. Available online: https://www.iso.org/standard/60857.html (accessed on 24 March 2019).

11. International Standard Organization, Geneva. ISO 31000:2018 Risk Management-Guidelines. Available online: https://www.iso.org/iso-31000-risk-management.html (accessed on 24 March 2019).

12. International Standard Organization, Geneva. ISO 22000:2018 Food Safety Management System-Requirements for Any Organization in the Food Chain. Available online: https://www.iso. org/standard/65464.html (accessed on 24 March 2019).

13. Susanto, A.; Mulyono, N.B. Risk assessment method for identification aspects and impacts at ore processing industry in Indonesia. J. Ecol. Eng. 2018, 19, 72-80. [CrossRef]

14. Decree of Ministry of Environmental of the Republic of Indonesia. No. 115 Year 2003 about Guidelines for Determining Status of Water Quality. Available online: http://jdih.menlh.go.id/pdf/ind/IND-PUU-7-2003Kepmen\%20115\%20Th\%202003\%20(Ped\%20Penet\%20elas\%20Air).pdf (accessed on 23 March 2019).

15. Regulation of Ministry of Health of the Republic of Indonesia. No. 32 Year 2017 about Quality Standard of Environmental Health and Water Health Status for Demand of Hygiene Sanitation, Swimming Pool, Solus per Aqua, and Public Bath House. Available online: http://hukor.kemkes.go.id/uploads/produk_hukum/PMK_No._32_ttg_Standar_Baku_Mutu_Kesehatan_ Air_Keperluan_Sanitasi,_Kolam_Renang,_Solus_Per_Aqua_.pdf (accessed on 24 March 2019).

16. Shams, S.; Ahsan, A.; Al-Mamun, A. Physical risk assessment for urban water supply in a developing country: A case of mega city Dhaka. Eng. J. 2015, 30, 23-31. [CrossRef]

17. USEPA. Wastewater Technology Fact Sheet, Screening and Grit Removal. Available online: https://www3. epa.gov/npdes/pubs/final_sgrit_removal.pdf (accessed on 17 April 2019).

18. Koyuncu, I.; Sengur, R.; Turken, T.; Guclu, S.; Pasaoglu, M.E. Advances in Membrane Technologies for Water Treatment, Materials, Processes and Applications; Woodhead Publishing Series in Energy: Sawston, Cambridge, UK, 2015; pp. 83-128.

19. Asian Development Bank. Guidance Note: Urban Water Supply Sector Risk Assessment. Available online: https:/www.adb.org/sites/default/files/institutional-document/31321/guidance-note-urbanwater-supply-sector-risk-assessment.pdf (accessed on 22 March 2019).

20. Deere, D.; Stevens, M.; Davidson, A.; Helm, G.; Dufour, A. Management strategies. In Water Quality: Guidelines, Standards and Health; Fewtrell, L., Bartram, J., Eds.; IWA Publishing: London, UK, 2001; pp. 257-288.

21. Godfrey, S.; Niwagaba, C.; Howard, G.; Tibatemba, S. Water Safety Plans for Developing Countries-A Case Study from Kampala, Uganda; Water, Engineering and Development Center (WEDC): Loughborough, UK, 2002. 
22. Decree of Ministry of Environmental of the Republic of Indonesia. No. 37 Year 2003 about Water Quality Analysis Methods and Water Sampling Methods. Jakarta. 2003. Available online: https://www.hukumonline.com/pusatdata/detail/1t4ca307ff630da/node/lt511a1360e8f8d/ keputusan-menteri-negara-lingkungan-hidup-nomor-37-tahun-2003/ (accessed on 11 April 2019).

23. Government Regulation of the Republic of Indonesia. No. 66 Year 2014 about Environmental Health. Gazette No. 184. Jakarta. 2014. Available online: http://kesmas.kemkes.go.id/perpu/konten/pp/pp-no.-66.tentangkesehatan-lingkungan-pdf (accessed on 10 April 2019).

24. Decree of Ministry of Health of the Republic of Indonesia. No. 876/MENKES/SK/VIII/2001 about Technical Guidelines of Environmental Health Impact Analysis. Available online: https: //www.hukumonline.com/pusatdata/detail/20799/node/1t50ed17cb7a520/keputusan-menteri-kesehatanno-876_menkes_sk_viii_2001-tahun-2001-pedoman-teknis-analisis-dampak-kesehatan-lingkungan (accessed on 11 April 2019).

25. Rossman, L.A.; Clark, R.M.; Grayman, W.M. Modeling Chlorine Residuals in Drinking-Water Distribution Systems. J. Environ. Eng. 1994, 120, 803-820. [CrossRef]

26. USEPA. EPANET 2 User Manual. Available online: https://nepis.epa.gov/Adobe/PDF/P1007WWU.pdf (accessed on 10 April 2019).

27. Drinking Water Quality Management Plan, Guidance Notes and Template for Drinking Water Services Providers. Available online: https:/www.qldwater.com.au/drinking-water-quality-management-plans (accessed on 15 April 2019).

28. Susanto, A.; Purwanto, P.; Hadiyarto, A. Analisis kualitas air untuk konsentrasi fluoride pada sistem jaringan distribusi air minum dengan fluoridasi. Ensains J. 2019, 1, 11-18. [CrossRef]

29. Haider, H.; Sadiq, R.; Tesfamariam, S. Performance indicators for small- and medium-sized water supply systems: A review. Environ. Rev. 2014, 22, 1-40. [CrossRef]

30. Lockhart, G.; Oswald, W.E.; Hubbard, B.; Medlin, E.; Gelting, R.J. Development of indicators for measuring outcomes of water safety plans. J. Water Sanit. Hyg. Dev. 2014, 4, 171-181. [CrossRef] [PubMed]

(C) 2019 by the authors. Licensee MDPI, Basel, Switzerland. This article is an open access article distributed under the terms and conditions of the Creative Commons Attribution (CC BY) license (http://creativecommons.org/licenses/by/4.0/). 